\title{
Simplified isolation and enrichment of spermatogonial stem-like cells from pubertal domestic cats (Felis catus)
}

\author{
Narong TIPTANAVATTANA ${ }^{1)}$, Mongkol TECHAKUMPHU ${ }^{1)}$ and Theerawat THARASANIT ${ }^{1) *}$ \\ ${ }^{1)}$ Department of Obstetrics, Gynaecology and Reproduction, Faculty of Veterinary Science, Chulalongkorn University, Bangkok 10330, \\ Thailand
}

(Received 5 April 2015/Accepted 19 May 2015/Published online in J-STAGE 14 June 2015)

\begin{abstract}
The efficiency of spermatogonial stem cell (SSC) isolation and culture from pubertal donors is currently poor primarily, because of contamination with other testicular cells. This study aimed to purify SSC-like cells using different extracellular matrixes and a discontinuous gradient density. In experiment 1 , testes $(n=6)$ were analyzed for histology and SSC-related protein expressions (laminin, SSEA-4, DDX-4 and GFR $\alpha-1)$. After enzymatic digestion, the cell suspension was plated onto either a laminin- or gelatin-coated dish. The number of SSC-like cells was determined at 15, 30 and 60 min of culture (experiment 2). Experiment 3 was performed to test whether or not the additional step of Percoll gradient density centrifugation could really improve purification of SSC-like cells. Testicular histology revealed complete spermatogenesis with laminin expression essentially at the basal lamina of the seminiferous tubules. SSEA-4 and GFR $\alpha-1$ colocalized with DDX-4 in the spermatogonia. The relative percentage of SSC-like cells, as determined by cells expressing SSEA-4 (59.42 $\pm 2.18 \%)$ and GFR $\alpha-1(42.70 \pm 1.28 \%)$, revealed that the highest SSC-like cell purity was obtained with the 15 -min laminin-coated dish compared with other incubation times and gelatin treatment $(P<0.05)$. Percoll treatment prior to laminin selection $(15$ min) significantly improved SSC-like cell recovery $(91.33 \pm 0.14 \%, P<0.001)$ and purity $(83.82 \pm 2.05 \%$ for SSEA-4 and $64.39 \pm 1.51 \%$ for GFR $\alpha-1, P<0.05)$. These attached cells demonstrated a typical SSC-like cell morphology and also expressed POU5F1, RET and ZBTB16 mRNA. In conclusion, double enrichment with Percoll gradient density centrifugation and laminin plating highly enriched the SSC-like cells population. KEY WORDS: extracellular matrix, feline, purity, spermatogonial stem cell
\end{abstract}

doi: 10.1292/jvms.15-0207; J. Vet. Med. Sci. 77(11): 1347-1353, 2015

Spermatogenesis is a complex process of male germ cell production, in which diploid spermatogonia or spermatogonial stem cells (SSCs) transform and differentiate into haploid spermatozoa within seminiferous tubules. This process is regulated by intra- and extra-testicular factors and continues throughout the pubertal period in men and animals. Although the SSCs hold a great promise for the treatment of infertility problems in men due, for example, to premature loss of male germ cells following cytotoxic chemotherapy, these SSCs can also be used for propagation and preservation of the genetic profiles of valuable male animals, such as endangered species [20]. In addition, SSCs have recently been reported to be capable of differentiation into 3 germ layers of embryos including cardiomyocytes, smooth muscle cells, neural cells, endothelial cells, hepatocytes and renal tubular cells $[4,6,7,10,21]$. The SSCs have therefore become an emerging model for regenerative medicine. SSCs are a subpopulation of spermatogonia type A that settle on the basal lamina of the seminiferous tubule. The number of SSCs, however, has been estimated to be only $0.03 \%$ of the total testicular cells in the adult rat testis[37]. Thus, purifica-

\footnotetext{
*Correspondenc to: Tharasanit, T., Department of Obstetrics, Gynaecology and Reproduction, Faculty of Veterinary Science, Chulalongkorn University, Bangkok 10330, Thailand.

e-mail: theerawat.t@chula.ac.th

(C)2015 The Japanese Society of Veterinary Science

This is an open-access article distributed under the terms of the Creative Commons Attribution Non-Commercial No Derivatives (by-nc-nd) License $<$ http://creativecommons.org/licenses/by-nc-nd/3.0/>.
}

tion of SSCs from the digested pubertal testis has become an important step for isolation of SSCs, since this technique eliminates the somatic testicular cells that interfere with the proliferation of SSCs in vitro [23, 37]. Several studies in the mouse, rat and bull have reported efficient techniques for SSC enrichment including plating with different coating substances, discontinuous Percoll ${ }^{\mathrm{TM}}$ gradient density centrifugation and fluorescence-activated/magnetic-activated cell sorting (FACs/MACs) [8, 12, 15, 26, 34]. The SSCs surrounded by Sertoli cells are adhered to the basal lamina of seminiferous tubules by various extracellular matrixes (ECMs) [35]. These ECMs are important for attachment of the testicular cells to the basal lamina of seminiferous tubules and also for the formation of the SSC niche [34]. Various types of ECMs have been used to purify the SSC population, such as laminin, fibronectin, collagen type I and IV and gelatin $[18,19,28]$. Of substrates used to coat the culture dish, gelatin has generally been used, because it is cost-effective for optimization of cell attachment in various cell types, such as fibroblasts. The gelatin plays a role in denaturing collagen, as connective tissue, and also interacts with laminin and fibronectin. Although the efficiency of laminin in selecting SSCs in the domestic cat has yet to be examined, the laminin-coated plate has been demonstrated to improve the purifying efficacy of SSC isolation by 3.3-, 5- to 7- and 8.5-folds in bull, mouse and rat SSCs, respectively $[13,31,35]$. This high efficiency of laminin for SSC selection has been postulated to be associated with its receptors on the SSCs [34]. Although the attachment of SSCs to laminin involves integrin proteins, a laminin receptor [15], 
$\alpha_{6}$-integrin, was the only specific surface marker of SSCs in the mouse [34]. In addition to plating selection, Percol$1^{\mathrm{TM}}$ purification, which involves nontoxic gradient density centrifugation, has been performed to recover the specific populations of testicular cells via different gradient density and centrifugation. This technique recovered approximately $80 \%, 72 \%$ and $96 \%$ of rat, buffalo and pig SSCs, respectively $[9,32,37]$. Moreover, the viability of SSCs recovered from Percoll ${ }^{\mathrm{TM}}$ was also improved [37].

The objective of this study was to examine the effects of types of ECM substrates and Percoll ${ }^{\mathrm{TM}}$ gradient density on the enrichment of SSC-like cells in pubertal domestic cats.

\section{MATERIALS AND METHODS}

\section{Experimental designs}

Experiment 1: The localization and immunolabeling of SSCs in pubertal cat testes

Cat testes $(n=6)$ were collected from pubertal domestic cats. The testes were fixed and sectioned for routine histology, immunohistochemistry (laminin) and immunofluorescence for SSC markers. Immunofluorescence was performed to demonstrate the co-expressions of SSEA-4/DDX-4 and GFR $\alpha-1 / D D X-4$ as SSC makers. The localization and expression pattern for each marker was descriptively analyzed.

\section{Experiment 2: The enrichment efficiency of SSCs using differ- ent types of ECMs}

The testes $(n=6)$ were dissociated into single cells by a modified 2-step enzymatic digestion [36]. The digested testicular cells $\left(0.5 \times 10^{6} \mathrm{cell} / \mathrm{cm}^{2}\right)$ were plated dishes coated with laminin $(20 \mu \mathrm{g} / \mathrm{m} l)$ and gelatin $(0.1 \%(\mathrm{w} / \mathrm{v}))$ coated dishes for 15,30 and $60 \mathrm{~min}$. The attached testicular cells were fixed and examined for SSEA-4 and GFR $\alpha-1$ expression using fluorescent microscopy. The percentages of SSEA $-4^{+}$and GFR $\alpha-1^{+}$from different types of ECMs among the different time points were analyzed.

\section{Experiment 3: Double enrichment of the SSC population with Percoll $^{T M}$ and laminin plating}

Suspension of dissociated testicular cells $(n=6,2 \times$ $10^{6} \mathrm{cell} / \mathrm{m} l$ ) was first layered onto a discontinuous Percoll ${ }^{\mathrm{TM}}$ gradient as previously described [26] with some modifications. The Percoll ${ }^{\mathrm{TM}}$ layers containing SSC-like cells were subsequently plated onto laminin-coated dishes for $15 \mathrm{~min}$. The SSEA $-4^{+}$and GFR $\alpha-1^{+}$cells were determined. In addition, the attached cells were collected for a study of SSCrelated gene expression (POU5F1, RET and ZBTB16) and a differentiation marker (KIT).

Animals and sample preparation: Tomcats (aged between 1-2 years old) were used in this study. Cat testes were consentingly collected following routine castration at the Veterinary Public Health Division of the Bangkok Metropolitan Administration, Bangkok, Thailand. The testes were transported to the laboratory in saline solution supplemented with antibiotics (100 IU/m $l$ penicillin and $100 \mu \mathrm{g} / \mathrm{m} l$ streptomycin) at room temperature. They were dissected from extraneous testicular tissues prior to use. The testes were divided for fixation with $4 \%(\mathrm{w} / \mathrm{v})$ paraformaldehyde in phosphate-buffered saline (PBS) (Exp. 1) and for dissociation with enzymatic digestion (Exp. 2 and 3 ).

Histology, immunohistochemistry and immunofluorescence: For histology and immunohistochemistry, testicular tissue was fixed with 4\% (w/v) paraformaldehyde (BDH Prolabo, VWR, Poole, U.K.) in PBS at $4^{\circ} \mathrm{C}$ (overnight). The fixed testes were embedded in paraffin and cut at a thickness of $4 \mu \mathrm{m}$. Hematoxylin and eosin staining was used to study the structures of the testis.

To detect the expression of laminin, a 3-step indirect immunoperoxidase immunohistochemistry (IHC) was performed with a Leica Microsystems BOND-MAX System (Leica Microsystems, Bannockburn, IL, U.S.A.). Briefly, the epitopes of the antigen were retrieved with Bond Epitope Retrieval Solution 2 (Leica Microsystems) for $20 \mathrm{~min}$ at $100^{\circ} \mathrm{C}$. The slides were incubated with an anti-mouse monoclonal laminin antibody diluted 1:100 (Novocastra $^{\mathrm{TM}}$, Leica Microsystems) at $25^{\circ} \mathrm{C}$ for $45 \mathrm{~min}$. Post Primary Polymer (Leica Microsystems) was applied for $9 \mathrm{~min}$ and followed with Polymer Poly-HRP IgG (Leica Microsystems) for 7 min. Mouse IgG (PP54, Millipore, Darmstadt, Germany) was used instead of the primary antibody for the negative control.

For immunofluorescence (IF) on paraffin-embedded sections, the epitope was unmasked by microwave treatment at 900 watts for $15 \mathrm{~min}$ in citric acid buffer (BDH Prolabo; $\mathrm{pH}=6.0)$ supplemented with $0.03 \%(\mathrm{v} / \mathrm{v})$ Triton X-100. Nonspecific staining was blocked using $3 \%(\mathrm{w} / \mathrm{v})$ bovine serum albumin (BSA) in PBS. The sections were firstly incubated at $4^{\circ} \mathrm{C}$ overnight with either mouse monoclonal SSEA-4 (1:200, Abcam, Cambridge MA, U.S.A.) or mouse monoclonal GFR $\alpha-1$ (1:200, sc-10716, Santa Cruz Biotechnology, Dallas, TX, U.S.A.). They were further incubated with the corresponding secondary antibody (goat anti-mouse IgG TRITC, 1:200). Subsequently, the sections were co-stained with the primary antibody (rabbit polyclonal DDX-4, 1:100, Abcam) and followed by goat anti-rabbit IgG FITC (1:100, Abcam). For the negative control, the staining procedures were identically performed as described above except that the primary antibodies were replaced with mouse IgG (PP54, Millipore, Darmstadt, Germany) or rabbit IgG (PP64, Millipore). The co-expression of SSEA-4/DDX-4 and GFR $\alpha-1 /$ DDX-4 markers was visualized with a fluorescence microscope (BX5, Olympus, Tokyo, Japan).

The photomicrographs obtained from histology, IHC and IF were recorded using the cellSens software (Olympus) and Adobe Photoshop CS6 Version 13.0.1 (Adobe Systems, San Jose, CA, U.S.A.).

For digested testicular cells, the cell suspension or attached cells were fixed with $4 \%(\mathrm{w} / \mathrm{v})$ paraformaldehyde in PBS for $24 \mathrm{hr}$ at $4^{\circ} \mathrm{C}$ and then labeled with primary and secondary antibodies as mentioned above (SSEA-4/TRITC, GFR $\alpha-1 /$ TRITC). The fixed cells were also blocked with $3 \%$ $(\mathrm{w} / \mathrm{v}) \mathrm{BSA}$ in PBS to reduce nonspecific background stain- 

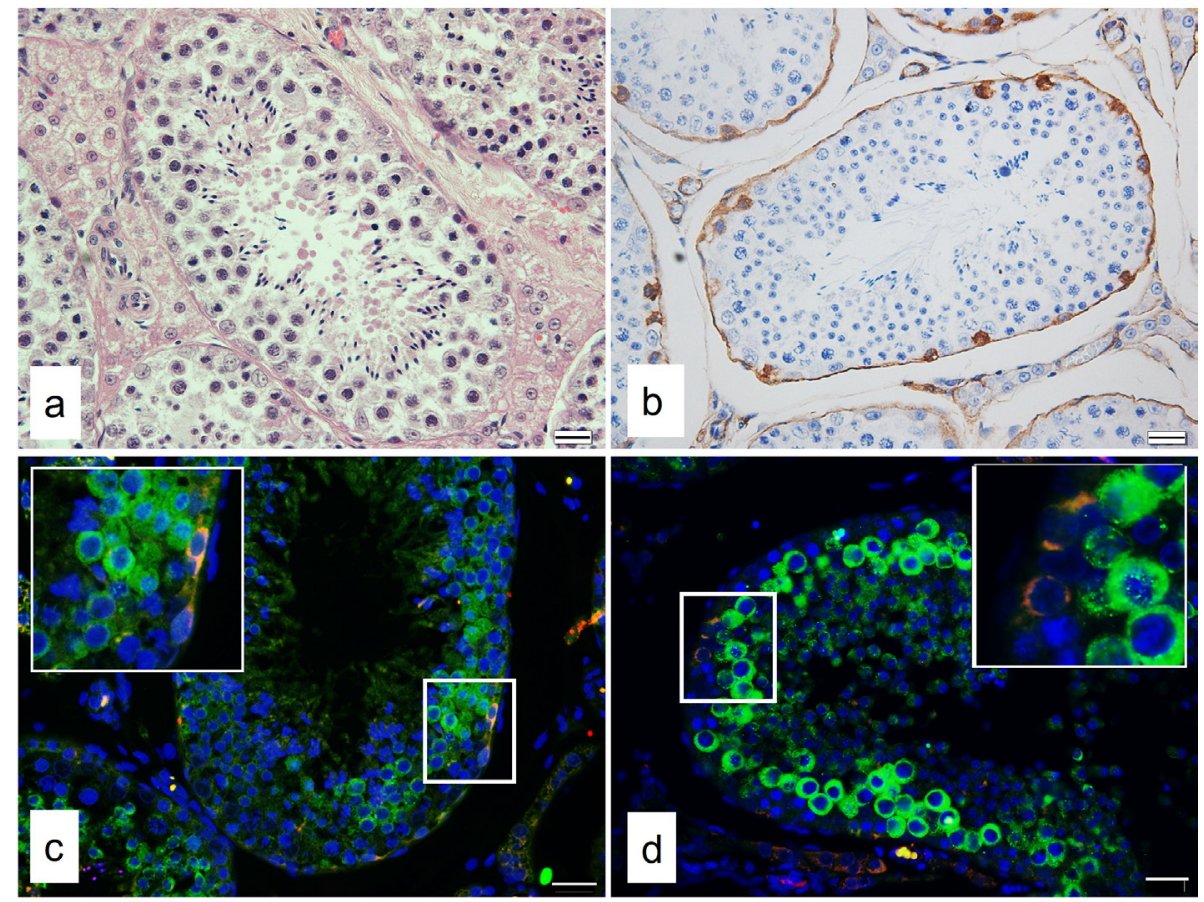

Fig. 1. Histology of testicular sections. (a) The pubertal cat testes contain spermatogonia, primary and secondary spermatocytes, round and elongated spermatids and spermatozoa in the seminiferous tubule, indicating complete spermatogenic differentiation of spermatogonia. (b) The cat testes express laminin at the basal lamina of the seminiferous tubules, blood vessels and interstitial parts. Laminin expression is also present at the extracellular matrixes surrounding the SSCs. (c and d) SSEA-4 (closed up, c) and GFR $\alpha-1$ (closed up, d) are co-expressed with DDX-4 in the spermatogonia present on the basal lamina of the seminiferous tubules. DDX-4 (green), as a universal germ cell lineage marker, is also present with high intensity in secondary spermatocytes and round spermatids. Negative controls did not show an immunoreaction (data were not shown). Scale bar $=20 \mu \mathrm{m}$.

ing.

Viability test and enrichment of SSC-like cells: Testes were enzymatically dissociated to obtain single testicular cells as previously described [36]. The testicular cells were examined for viability in terms of esterase enzyme activity (calcein AM staining) and plasma membrane integrity (ethidium homodimer-1, Molecular Probes, Life Technologies, Carlsbad, CA, U.S.A.).

For differential plating selection, the culture dishes were first coated with either $20 \mu \mathrm{g} / \mathrm{m} l$ laminin or $0.1 \%(\mathrm{w} / \mathrm{v})$ gelatin at $37^{\circ} \mathrm{C}$ for $4 \mathrm{hr}$ before cell plating. The dissociated testicular cells $\left(0.5 \times 10^{6}\right.$ cells $\left./ \mathrm{cm}^{2}\right)$ were plated onto laminin- or gelatin-coated dishes. The cells were further incubated for 15,30 and $60 \mathrm{~min}$, and then, the samples were fixed and collected for immunostaining. Culture was performed at $37^{\circ} \mathrm{C}$ in a moisture incubator with $5 \% \mathrm{CO}_{2}$ in air.

Percoll ${ }^{\mathrm{TM}}$ gradient density centrifugation was performed by layering the cell suspension $\left(2 \times 10^{6}\right.$ cells $\left./ \mathrm{m} l\right)$ onto $30 \%, 45 \%, 60 \%$ and $90 \%(\mathrm{v} / \mathrm{v})$ isotonic Percoll ${ }^{\mathrm{TM}}$ solution, respectively. The cells were then centrifuged at $800 \times$ $g$ for $30 \mathrm{~min}$ at $25^{\circ} \mathrm{C}$. The thin layers of cell suspension at interfaces between the two concentrations of Percoll ${ }^{\mathrm{TM}}$ were gently collected.

RT-PCR for SSC-related gene expression: The attached testicular cells were collected and extracted to obtain total RNA using an Absolutely RNA Nanoprep Kit (Stratagene ${ }^{\mathrm{TM}}$, Agilent Technologies, Santa Clara, CA, U.S.A.). The total RNA $(2 n \mathrm{~g} / \mu l)$ was reversely transcribed using the SuperScript $^{\mathrm{TM}}$ III First-Strand Synthesis System for RT-PCR (Invitrogen, Carlsbad CA, U.S.A.) for cDNA synthesis (RT+). Removal of SuperScript ${ }^{\mathrm{TM}}$ III reverse transcriptase was performed for the negative control (RT-). PCR was performed with RT+ and RT- cDNA using GoTag ${ }^{\circledR}$ Green Master Mix (Promega, Fitchburg, WI, U.S.A.). In brief, the PCR conditions consisted of denaturation $\left(2 \mathrm{~min}\right.$ at $\left.95^{\circ} \mathrm{C}\right) ; 30$ cycles of $30 \mathrm{sec}$ at $95^{\circ} \mathrm{C}, 30 \mathrm{sec}$ at the annealing temperature for each primer and $30 \mathrm{sec}$ at $72^{\circ} \mathrm{C}$; and final extension $(2 \mathrm{~min}$ at $\left.72^{\circ} \mathrm{C}\right)$. The PCR products were electrophoresed in $1 \%(\mathrm{w} / \mathrm{v})$ agarose gel (Bio-Rad, Hercules, CA, U.S.A.) supplemented with 5\% (v/v) RedSafe ${ }^{\mathrm{TM}}$ Nucleic Acid Stain Solution (iNtRON Biotechnology, Gyeonggi-do, South Korea) in TBE buffer. The products were detected by a Gel Documentation system (Syngene, Cambridge, U.K.).

The primers and annealing temperatures used in this study were as follows: POU5F1 (5'-TGAGAGGCAACCTGGAGAAC- $3^{\prime}$ and $5^{\prime}$-AACCACACTCGGACCACATC- $3^{\prime}, 55^{\circ} \mathrm{C}, 112$ bp, accession number: EU366914), RET (5'-TGTGCATGACTACAGGCTGG-3' and 5'-CCTGCTCACAGTGAAGGT- 

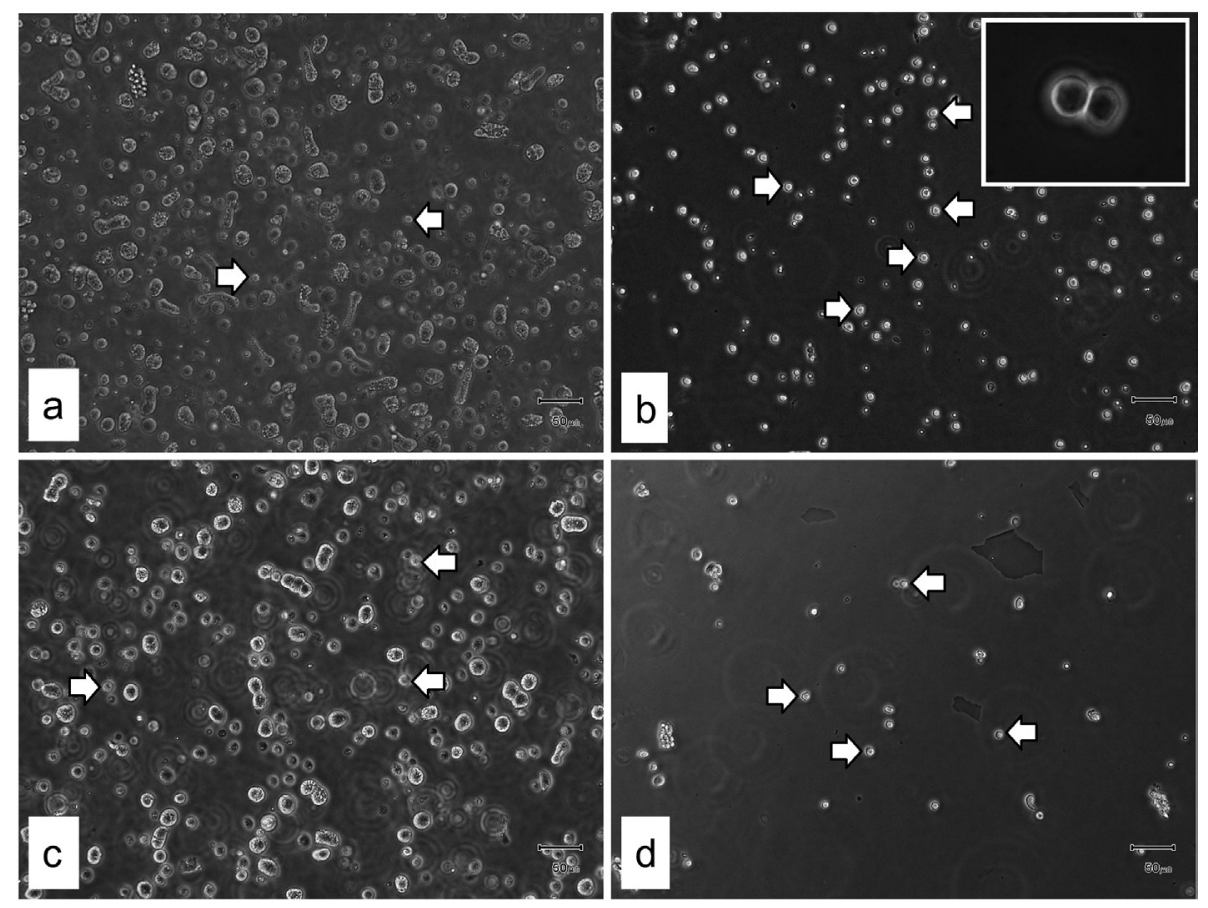

Fig. 2. Morphology of testicular cells after testicular cell digestion and enrichment. Following a modified 2-step enzymatic digestion, testicular cells contain several stages of spermatogenesis (a). Laminin was successfully used to enrich morphologically undifferentiated spermatogonia (or SSC-like cells (arrow)) (b). The SSC-like cells are round to oval in shape and have a high nucleus/cytoplasm ratio (closed up, b). Percoll ${ }^{\mathrm{TM}}$ gradient density treatment (c and d, at $30 \%$ layer, c and $30 \% / 45 \%$ interface, respectively), improved cell viability and cell purity. Scale bar $=50 \mu \mathrm{m}$.

GT-3', 63ㄷ, 193 bp, accession number: XM_003994195.1), ZBTB16(5'-GCAAGAAGTTCAGCCTCAAGC-3' and 5'- GCTTGATCATGGCCGAGTAGTC-3', 63', 119 bp) [36] and $K I T\left(5^{\prime}-\mathrm{TCCTGCT}\right.$ CCGCGTCCAGACA-3' and 5'-CTTGCCCTTCCGGTCCGCAG-3', 60 C, 533 bp) [36]. GAPDH was used as a housekeeping gene [36].

Statistical analysis: The percentages of SSEA $-4^{+}$and GFR $\alpha-1^{+}$testicular cells and viability were expressed as the mean \pm SEM. The data were analyzed with SPSS Statistics Version 20.0.0 (IBM Corporation, Armonk, NY, U.S.A.). The statistical differences between the groups were tested by analysis of variance (ANOVA) followed by the Bonferroni post hoc test. Differences between values with $P<0.05$ were considered statistically significant.

\section{RESULTS}

The localization and immunolabeling of SSCs in pubertal cat testes: Histological examination of pubertal cat testes demonstrated fully differentiation of male germ cells in the seminiferous tubules. Spermatogonia including SSCs resided on the basal lamina of the seminiferous tubule and were surrounded by Sertoli cells. The spermatogonia differentiated into spermatocytes, spermatids and spermatozoa (Fig. 1a). For IHC of laminin, expression of this protein was observed in the spermatogonia present at the basal lamina of the seminiferous tubules. Laminin was also essentially expressed at the extracellular matrixes of the testis, such as the basal lamina of seminiferous tubules and blood vessels (Fig. 1b). The spermatogonia (SSCs) expressed SSEA-4 at the plasma membrane and cytoplasm. These cells coexpressed with DDX-4 (Fig. 1c). However, DDX-4 was also detected in other testicular germ cells, such as spermatocytes and round spermatids. Similar to SSEA- $4^{+}$, co-expression of GFR $\alpha-1$ and DDX-4 was clearly observed in the spermatogonia located on the basal lamina (Fig. 1d).

The enrichment efficiency of SSCs using different types of ECMs: After enzymatic isolation, the viability of isolated testicular cells was $66.56 \pm 1.43 \%$. The percentages of SSEA $-4^{+}$and GFR $\alpha-1^{+}$testicular cells attached to different ECMs are shown in Table 1. On the laminin-coated surface, adhered SSC-like cells had a typical SSC-like cell morphology as shown in a previous study. They were round to oval cells (ranged $8-13 \mu \mathrm{m}$ of size) with an increased nucleus/ cytoplasm ratio (Fig. 2b). However, all attached testicular cells were contaminated with mixed populations of other testicular cells, such as Sertoli cells, fibroblasts, spermatids and other testicular cells. The laminin-coated plate technique significantly enriched the SSEA-4 $4^{+}$population of testicular cells when examined at $15(59.42 \pm 2.18 \%)$ and $30 \mathrm{~min}$ $(53.37 \pm 1.08 \%)$ of incubation. These percentages were significantly higher than the percentage for non-treatment $(27.24 \pm 1.29 \%, P<0.001)$. GFR $\alpha-1$ testicular cells tended to increase in cell number at $15(42.70 \pm 1.28 \%)$ and 30 
Table 1. Efficiency of differential plating with laminin and gelatin at 15, 30 and 60 min of incubation

\begin{tabular}{|c|c|c|c|c|c|c|c|}
\hline \multirow{3}{*}{$\begin{array}{c}\text { Marker } \\
(\%)\end{array}$} & \multirow{3}{*}{ Non-treatment } & \multicolumn{6}{|c|}{ Differential plating } \\
\hline & & \multicolumn{2}{|c|}{$15 \mathrm{~min}$} & \multicolumn{2}{|c|}{$30 \mathrm{~min}$} & \multicolumn{2}{|c|}{$60 \mathrm{~min}$} \\
\hline & & Laminin & Gelatin & Laminin & Gelatin & Laminin & Gelatin \\
\hline SSEA-4 ${ }^{+}$ & $27.24 \pm 1.29^{\dagger}$ & $59.42 \pm 2.18^{\S, \mathrm{a}, \mathrm{A}}$ & $9.05 \pm 1.07^{\S, \mathrm{b}, \mathrm{A}, \mathrm{B}}$ & $53.37 \pm 1.08^{\S, \mathrm{a}, \mathrm{B})}$ & $14.68 \pm 0.94^{\S, \mathrm{b}, \mathrm{A})}$ & $16.77 \pm 2.59^{\S, \mathrm{a}, \mathrm{C})}$ & $5.34 \pm 0.22^{\S, \mathrm{b}, \mathrm{B})}$ \\
\hline $\mathrm{GFR} \alpha-1^{+}$ & $37.11 \pm 1.61^{\dagger, \S}$ & $42.70 \pm 1.28^{\dagger, \mathrm{a}, \mathrm{A}}$ & $10.97 \pm 0.84^{\S, \mathrm{b}, \mathrm{A}}$ & $41.71 \pm 2.17^{₫, a, A)}$ & $5.30 \pm 1.18^{\S, \mathrm{b}, \mathrm{A}, \mathrm{B})}$ & $20.90 \pm 1.06^{\S, \mathrm{a}, \mathrm{B})}$ & $2.00 \pm 0.17 \S, \mathrm{b}, \mathrm{B})$ \\
\hline
\end{tabular}

Different superscripts within the same row indicate values that are significantly different $(P<0.05)$. $\dagger, \S$, $₫$ All groups of differential plating compared with before differential plating. a,b) Laminin compared with gelatin within the same time. A,B) Times of incubation compared within the same substrate.

$(41.71 \pm 2.17 \%)$ min of incubation $(P>0.05)$. However, the numbers of SSEA $-4^{+}$and GFR $\alpha-1^{+}$testicular cells examined at $60 \mathrm{~min}$ of incubation decreased significantly to 16.77 $\pm 2.59 \%$ and $20.90 \pm 1.06 \%$, respectively $(P<0.001)$. The numbers of SSEA- $4^{+}$and GFR $\alpha-1^{+}$cells attached to gelatin were significantly lower compared with those attached to laminin at all incubation times (Table $1, P<0.001$ ). The attached SSEA- $4^{+}$and GFR $\alpha-1^{+}$cells on gelatin-coated dishes also decreased significantly from $9.05 \pm 1.07 \%$ to $5.34 \pm$ $0.22 \%$ and $10.97 \pm 0.84 \%$ to $2.00 \pm 0.17 \%$ when examined at 15 and $30 \mathrm{~min}$, respectively $(P<0.001)$. The gelatin-bound cells at 60 min of incubation were the highly contaminated with attached fibroblasts.

Double enrichment of SSCs with Percoll ${ }^{T M}$ and laminin plating: After discontinuous Percoll ${ }^{\mathrm{TM}}$ gradient density centrifugation, the majority of testicular cells were found at 2 Percoll $^{\mathrm{TM}}$ densities (at 30\% and the interface between $30 \%$ and $45 \%$ solutions $(30 \% / 45 \%))$. Spermatozoa, red blood cells and other cell debris were observed at other Percoll $^{\mathrm{TM}}$ interfaces. A thin layer of testicular cells at $30 \%$ Percoll $^{\mathrm{TM}}$ yielded higher cell numbers than that obtained from the $30 \% / 45 \%$ interface (Fig. $2 \mathrm{c}$ and $2 \mathrm{~d}$ ). However, the viability rate of testicular cells at the $30 \% / 45 \%$ interface $(91.33 \pm 0.14 \%)$ was significantly higher than that of the $30 \%$ layer $(78.40 \pm 0.23 \%)$ and non-treatment $(66.56$ $\pm 1.43 \%)(P<0.001)$. Double enrichment with Percoll ${ }^{\mathrm{TM}}$ and Laminin (Percoll ${ }^{\mathrm{TM}}+$ Laminin) significantly improved SSEA $-4^{+}$and GFR $\alpha-1^{+}$cells when compared with only laminin treatment $(P<0.001)$. This double enrichment also improved cell uniformity. However, some sperm heads were also found in laminin-coated dishes (Fig. 2b). We confirmed that the attached cells derived from double enrichment with Percoll ${ }^{\mathrm{TM}}+$ Laminin expressed the SSC-related genes (POU5F1, RET and ZBTB16 mRNA) but that the differentiated gene (KIT mRNA) was absent (Fig. 3).

\section{DISCUSSION}

This study revealed that only small numbers of testicular cells demonstrated morphologic and phenotypic SSC characteristics within pubertal testes of domestic cats. The limited numbers of SSC-like cells have been proposed to attenuate the success of SSC-like cell isolation and culture. The enrichment step has therefore become a critical part for establishment of SSCs in vitro, especially for species in which well-characterized SSCs have yet to be reported. In

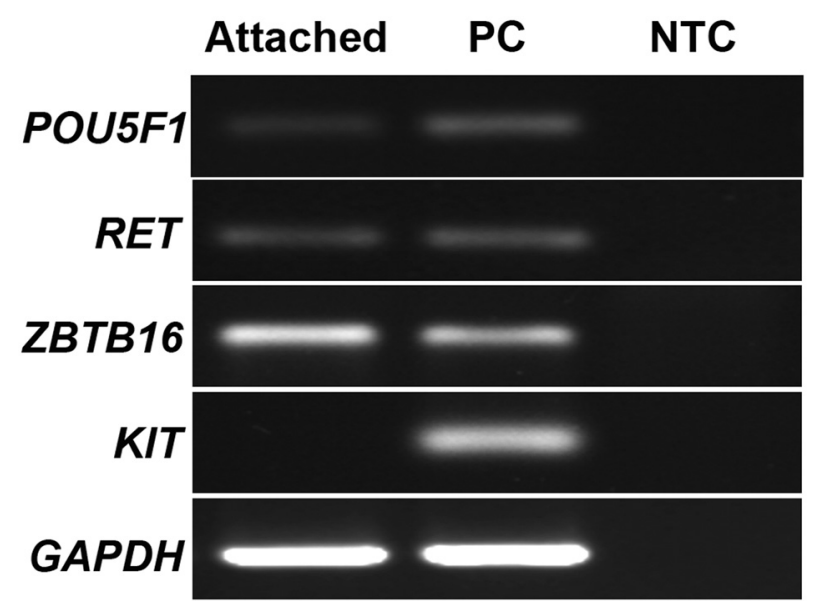

Fig. 3. The mRNA expression of POU5F1, RET, ZBTB16 and KIT. The RT-PCR products of laminin-attached testicular cells from the $30 \% / 40 \%$ interface (attached), positive control (PC) and no template control (NTC).

the domestic cat, the criteria for characterization of SSCs have been limited, and functional tests of SSCs by means of colonization with proliferative activity following transplantation have remained unsuccessful $[20,35]$. An indirect assay for cat SSC characterization, including determination of the expression of SSC markers at the mRNA and protein levels, was used in this study. Until recently, the definitive markers for SSC characterization have not been entirely addressed. However, many proteins have been universally used as putative SSC markers for studying and enrichment of SSCs, such as glial cell line-derived neurotrophic growth factor (GDNF) family receptor $\alpha-1$ (GFR $\alpha-1), \alpha_{6} \beta_{1}$-integrins, epithelial cell adhesion molecule (EpCAM), promyelocytic leukemia zinc finger (PLZF or ZBTB16), thymus cell antigen-1 (Thy-1 or CD90) and stage-specific embryonic antigen-4 (SSEA-4) $[5,11,17,22,24,27,30,34]$. Although there is no single marker that can ultimately be used to determine the SSC population, our study (experiment 1) confirmed that SSEA-4 and GFR $\alpha-1$ were co-localized specifically at the spermatogonia located on the basal lamina of seminiferous tubules. Moreover, both SSEA-4 and GFR $\alpha-1$ markers were coexpressed with DDX-4, defining a specific marker for germ cell lineage [33]. GDNF binds and signals via glycosylphos- 
Table 2. Efficiency (mean \pm SEM) of the single (Laminin) and double (Percoll ${ }^{\mathrm{TM}}+$ Laminin) enrichment techniques

\begin{tabular}{lll}
\hline Enrichment technique & SSEA-4 $^{+}(\%)$ & GFR $\alpha-1^{+}(\%)$ \\
\hline Laminin & $59.42 \pm 2.18^{\mathrm{a})}$ & $42.70 \pm 1.28^{\mathrm{a})}$ \\
Percol1 ${ }^{\mathrm{TM}}+$ Laminin $(30 \% / 45 \%)$ & $\left.83.82 \pm 2.05^{\mathrm{b}}\right)$ & $64.39 \pm 1.51^{\mathrm{b}}$ \\
\hline
\end{tabular}

a,b) Different superscripts indicate values that differ significantly $(P<0.05)$.

phatidyl inositol GFR $\alpha-1$ surface receptors and its RET tyrosine kinase co-receptors in the cell plasma membrane $[2,13]$. This GDNF has been demonstrated to play a central role for in vivo and in vitro activities of SSCs [25, 26]. Our study also demonstrated that laminin, an extracellular matrix, surrounded the spermatogonia and was present at the basal lamina of the seminiferous tubules. Although attachment of SSCs to laminin involves integrin proteins, a laminin receptor [14], $\alpha_{6}$ - and $\beta_{1}$ integrins were the only specific marker of SSCs in mouse [34]. In this study, we found that purified SSC-like cells rapidly adhered to laminin-coated surfaces within $15 \mathrm{~min}$ of incubation (Table 1). This short incubation maximized the SSC-like cells with minimal contaminating cells, and therefore, it is recommended for SSC isolation, as similarly reported in a previous report in the mouse [35]. Prolonged incubation of cell suspensions from 15 to $60 \mathrm{~min}$ increased the numbers of several types including fibroblasts, spermatids and sperm [35]. Compared with the properties of laminin, the proportion of SSEA4 ${ }^{+}$and GFR $\alpha-1^{+}$testicular cells bound to gelatin decreased with increased incubation time (Table 1). This gelatin substrate would therefore be suitable for negative selection rather than purifying SSCs [8]. However, it is worth noting that the efficiency of a specific substrate for SSC enrichment in terms of time and the adhesive force between the cells and extracellular matrixes may solely rely on the number of its receptors on the surfaces of SSCs and the concentration of substrate used [3, 29]. This also appeared to be cell type and species specific. For example, buffalo SSCs were poorly selected using this technique [1]. Although differential plating with laminin could eliminate other contaminating testicular cells, the number of contaminating cells remained high (Tables 1 and 2). We therefore further tested whether or not enrichment with Percoll $^{\mathrm{TM}}$ gradient density centrifugation prior to laminin treatment would really enhance SSC purity. We found in the current study that the Percoll ${ }^{\mathrm{TM}}$ gradient could select cells based on their cell size and shape, as previously reported in the bull and boar [12, 16, 29]. The double enrichment technique used significantly improved the purity of the SSC-like cells to $91.33 \pm 0.14 \%$, which is similar to the results in other reports $[12,15]$. Although we did not further culture selected cells for a longer period, the obtained cells were morphologically and phenotypically similar to SSCs, as previously reported [36]. Furthermore, the attached SSC-like cells obtained from the double enrichment (Percoll ${ }^{\mathrm{TM}}+$ Laminin) expressed POU5F1, RET and ZBTB16 mRNA (SSC markers), but the differentiation marker, KIT, was absent (Figs. 2b and 3).

In conclusion, we demonstrated that the SSC-like cells of domestic cats expressed SSEA-4 and GFR $\alpha-1$, which can be used as SSC markers. The SSC-like cells preferentially attached to laminin, but the purity of the cells was time dependent. This technique combined with the discontinuous Percoll $^{\mathrm{TM}}$ gradient density centrifugation significantly improved the viability and viability of SSC-like cells from the domestic cats. Double enrichment, in particular, can be applied as a prerequisite tool for in vitro culture of cat SSClike cells to enrich the SSC-like cell population.

\section{DECLARATION OF INTEREST}

The authors declare that there is no conflict of interest that could be perceived as prejudicing the impartiality of the research reported.

ACKNOWLEDGMENTS. This work was financially supported by a TRF-CHE Research Grant for mid-career University Faculty (RSA5680028) and the 90th Anniversary of Chulalongkorn University, Rachadapisek Sompote Fund. The authors thank Dr. P. Setthawong and Dr. C. Bhanmeechao for help in data collection. N. Tiptanavattana is the recipient of a scholarship from Chulalongkorn University Graduate Scholarship to Commemorate the 72nd Anniversary of His Majesty King Bhumibol Adulyadej.

\section{REFERENCES}

1. Ahmad, S., Xiao, Y., Han, L., Hua, H., Riaz, H., Liang, A. and Yang, L. G. 2013. Isolation, identification and enrichment of type a spermatogonia from the testis of chinese cross-bred buffaloes (swamp x river). Reprod. Domest. Anim. 48: 373-381. [Medline] [CrossRef]

2. Creemers, L. B., Meng, X., den Ouden, K., van Pelt, A. M., Izadyar, F., Santoro, M., Sariola, H. and de Rooij, D. G. 2002. Transplantation of germ cells from glial cell line-derived neurotrophic factor-overexpressing mice to host testes depleted of endogenous spermatogenesis by fractionated irradiation. Biol. Reprod. 66: 1579-1584. [Medline] [CrossRef]

3. de Barros, F. R. O., Worst, R. A., Saurin, G. C. P., Mendes, C. M., Assumpção, M. and Visintin, J. A. 2012 . $\alpha$-6 integrin expression in bovine spermatogonial cells purified by discontinuous percoll density gradient. Reprod. Domest. Anim. 47: 887-890. [Medline] [CrossRef]

4. De Chiara, L., Fagoonee, S., Ranghino, A., Bruno, S., Camussi, G., Tolosano, E., Silengo, L. and Altruda, F. 2014. Renal cells from spermatogonial germline stem cells protect against kidney injury. J. Am. Soc. Nephrol. 25: 316-328. [Medline] [CrossRef]

5. Grisanti, L., Falciatori, I., Grasso, M., Dovere, L., Fera, S., Muciaccia, B., Fuso, A., Berno, V., Boitani, C., Stefanini, M. and Vicini, E. 2009. Identification of spermatogonial stem cell subsets by morphological analysis and prospective isolation. Stem Cells 27: 3043-3052. [Medline]

6. Guan, K., Wolf, F., Becker, A., Engel, W., Nayernia, K. and Hasenfuss, G. 2009. Isolation and cultivation of stem cells from adult mouse testes. Nat. Protoc. 4: 143-154. [Medline] [CrossRef]

7. Guan, K., Nayernia, K., Maier, L., Wagner, S., Dressel, R., Lee, J., Nolte, J., Wolf, F., Li, M., Engel, W. and Hasenfuss, G. 2006. Pluripotency of spermatogonial stem cells from adult mouse testis. Nature 440: 1199-1203. [Medline] [CrossRef]

8. Hamra, F. K., Schultz, N., Chapman, K. M., Grellhesl, D. M., 
Cronkhite, J. T., Hammer, R. E. and Garbers, D. L. 2004. Defining the spermatogonial stem cell. Dev. Biol. 269: 393-410. [Medline] [CrossRef]

9. Han, N. R., Park, Y., Yun, J., Park, H., Park, M., Kim, M., Choi, J., Lee, E., Gong, S., Lim, J. and Lee, S. 2014. Determination of feeder cell-based cellular niches supporting the colonization and maintenance of spermatogonial stem cells from prepubertal domestic cat testes. Reprod. Domest. Anim. 49: 705-710. [Medline] [CrossRef]

10. Heer, R., Hepburn, A. C., Williamson, S. C., Kennedy, A., ElSherif, A., Soomro, N. A., Brown, C. D. and Robson, C. N. 2013. Renal differentiation from adult spermatogonial stem cells. Ren. Fail. 35: 1387-1391. [Medline] [CrossRef]

11. Hermann, B. P., Sukhwani, M., Lin, C.C., Sheng, Y., Tomko, J., Rodriguez, M., Shuttleworth, J. J., McFarland, D., Hobbs, R. M., Pandolfi, P. P., Schatten, G. P. and Orwig, K. E. 2007. Characterization, cryopreservation, and ablation of spermatogonial stem cells in adult rhesus macaques. Stem Cells 25: 2330-2338. [Medline] [CrossRef]

12. Herrid, M., Davey, R. J., Hutton, K., Colditz, I. G. and Hill, J. R. 2009. A comparison of methods for preparing enriched populations of bovine spermatogonia. Reprod. Fertil. Dev. 21: 393-399. [Medline] [CrossRef]

13. Hofmann, M. C., Braydich-Stolle, L. and Dym, M. 2005. Isolation of male germ-line stem cells; influence of GDNF. Dev. Biol. 279: 114-124. [Medline] [CrossRef]

14. Hynes, R. O. 1992. Integrins: versatility, modulation, and signaling in cell adhesion. Cell 69: 11-25. [Medline] [CrossRef]

15. Izadyar, F., Spierenberg, G. T., Creemers, L. B., den Ouden, K. and de Rooij, D. G. 2002. Isolation and purification of type A spermatogonia from the bovine testis. Reproduction 124: 85-94. [Medline] [CrossRef]

16. Izadyar, F., Wong, J., Maki, C., Pacchiarotti, J., Ramos, T., Howerton, K., Yuen, C., Greilach, S., Zhao, H., Chow, M., Chow, Y., Rao, J., Barritt, J., Bar-Chama, N. and Copperman, A. 2011. Identification and characterization of repopulating spermatogonial stem cells from the adult human testis. Hum. Reprod. 26: 1296-1306. [Medline] [CrossRef]

17. Kanatsu-Shinohara, M., Ogonuki, N., Inoue, K., Miki, H., Ogura, A., Toyokuni, S. and Shinohara, T. 2003. Long-term proliferation in culture and germline transmission of mouse male germline stem cells. Biol. Reprod. 69: 612-616. [Medline] [CrossRef]

18. Kanatsu-Shinohara, M., Muneto, T., Lee, J., Takenaka, M., Chuma, S., Nakatsuji, N., Horiuchi, T. and Shinohara, T. 2008. Long-term culture of male germline stem cells from hamster testes. Biol. Reprod. 78: 611-617. [Medline] [CrossRef]

19. Kim, B.G., Cho, C. M., Lee, Y.A., Kim, B.J., Kim, K.J., Kim, Y.H., Min, K.S., Kim, C. G. and Ryu, B.Y. 2010. Enrichment of testicular gonocytes and genetic modification using lentiviral transduction in pigs. Biol. Reprod. 82: 1162-1169. [Medline] [CrossRef]

20. Kim, Y., Selvaraj, V., Dobrinski, I., Lee, H., McEntee, M. C. and Travis, A. J. 2006. Recipient preparation and mixed germ cell Isolation for spermatogonial stem cell transplantation in domestic cats. J. Androl. 27: 248-256. [Medline] [CrossRef]

21. Ko, K., Tapia, N., Wu, G., Kim, J. B., Bravo, M. J., Sasse, P., Glaser, T., Ruau, D., Han, D. W., Greber, B., Hausdorfer, K., Sebastiano, V., Stehling, M., Fleischmann, B. K., Brustle, O., Zenke, M. and Scholer, H. R. 2009. Induction of pluripotency in adult unipotent germline stem cells. Cell Stem Cell 5: 87-96. [Medline] [CrossRef]
22. Kokkinaki, M., Djourabtchi, A. and Golestaneh, N. 2011. Longterm culture of human SSEA-4 positive spermatogonial stem cells (SSCs). J. Stem Cell Res. Ther. 2: 2488. [Medline]

23. Kubota, H. and Brinster, R. L. 2008. Culture of rodent spermatogonial stem cells, male germline stem cells of the postnatal animal. Methods Cell Biol. 86: 59-84. [Medline]

24. Kubota, H., Avarbock, M. R. and Brinster, R. L. 2003. Spermatogonial stem cells share some, but not all, phenotypic and functional characteristics with other stem cells. Proc. Natl. Acad. Sci. U.S.A. 100: 6487-6492. [Medline] [CrossRef]

25. Kubota, H., Avarbock, M. R. and Brinster, R. L. 2004. Culture conditions and single growth factors affect fate determination of mouse spermatogonial stem cells. Biol. Reprod. 71: 722-731. [Medline] [CrossRef]

26. Kubota, H., Avarbock, M. R. and Brinster, R. L. 2004. Growth factors essential for self-renewal and expansion of mouse spermatogonial stem cells. Proc. Natl. Acad. Sci. U.S.A. 101: 16489-16494. [Medline] [CrossRef]

27. Li, S., Shi, R., Wang, Q., Cai, J. and Zhang, S. 2012. Nanostructure and $\beta 1$-integrin distribution analysis of pig's spermatogonial stem cell by atomic force microscopy. Gene 495: 189-193. [Medline] [CrossRef]

28. Lim, J. J., Seol, D. W., Choi, K. H., Shin, D. H., Kim, H. J., Song, S-H. and Lee, D. R. 2014. Spermatogonial stem cell enrichment using simple grafting of testis and in vitro cultivation. Sci. Rep. 4: 5923 DOI: 59 [CrossRef]. [Medline]

29. Luo, J., Megee, S., Rathi, R. and Dobrinski, I. 2006. Protein gene product 9.5 is a spermatogonia-specific marker in the pig testis: application to enrichment and culture of porcine spermatogonia. Mol. Reprod. Dev. 73: 1531-1540. [Medline] [CrossRef]

30. Maki, C. B., Pacchiarotti, J., Ramos, T., Pascual, M., Pham, J., Kinjo, J., Anorve, S. and Izadyar, F. 2009. Phenotypic and molecular characterization of spermatogonial stem cells in adult primate testes. Hum. Reprod. 24: 1480-1491. [Medline] [CrossRef]

31. Orwig, K. E., Shinohara, T., Avarbock, M. R. and Brinster, R. L. 2002. Functional analysis of stem cells in the adult rat testis. Biol. Reprod. 66: 944-949. [Medline] [CrossRef]

32. Rafeeqi, T. and Kaul, G. 2013. Isolation and enrichment of type A spermatogonia from pre-pubertal buffalo (Bubalus bubalis) testis. Andrologia 45: 195-203. [Medline] [CrossRef]

33. Raz, E. 2000. The function and regulation of vasa-like genes in germ-cell development. Genome Biol. 1: reviews1017.1-reviews 1017.1016. [Medline] [CrossRef]

34. Shinohara, T., Avarbock, M. R. and Brinster, R. L. 1999. beta1and alpha6-integrin are surface markers on mouse spermatogonial stem cells. Proc. Natl. Acad. Sci. U.S.A. 96: 5504-5509. [Medline] [CrossRef]

35. Shinohara, T., Avarbock, M. R. and Brinster, R. L. 2000. Functional analysis of spermatogonial stem cells in steel and cryptorchid infertile mouse models. Dev. Biol. 220: 401-411. [Medline] [CrossRef]

36. Tiptanavattana, N., Thongkittidilok, C., Techakumphu, M. and Tharasanit, T. 2013. Characterization and in vitro culture of putative spermatogonial stem cells derived from feline testicular tissue. J. Reprod. Dev. 59: 189-195. [Medline] [CrossRef]

37. van Pelt, A. M., Morena, A. R., van Dissel-Emiliani, F. M., Boitani, C., Gaemers, I. C., de Rooij, D. G. and Stefanini, M. 1996. Isolation of the synchronized A spermatogonia from adult vitamin A-deficient rat testes. Biol. Reprod. 55: 439-444. [Medline] [CrossRef] 